\title{
En introduktion til Sergei Bulgakovs teologi
}

\author{
Kontrær logik og metafysisk ontologi
}

\section{Cand.theol. Kristian Mejrup}

\begin{abstract}
An overlooked chapter in a Danish theological context is the sophiology and theology of Sergei Bulgakov who developed a theology based on the humanity of God. The Russian sophiological tradition draws no clear line between theology and philosophy. It mingles German idealism with Greek patristics, and a view of God, Goodness, Truth and Beauty is defended in a world full of cracks, antinomies and fragments of the Truth. Sophiology offers a view of the world englobed in divinity. Creation is a creation ex nihilo but also out of a superabundance in the inner divinity of the Triune God. Sophiology does not understand itself to be a new doctrine, but an interpretation of the doctrine of the Incarnation and the Trinity. Following the line of thought in Sergei Bulgakov's sophiology, the relation between identity and difference is rendered clear as a relation between God and the world. This article will particularly investigate the Christological and Trinitarian aspects of Bulgakov's sophiology.
\end{abstract}

Key words: Russian Sophiology - Radical Orthodoxy - Sergei Bulgakov - Christology - Karl Barth - Trinity - Hans Urs von Balthasar - coincidentia oppositorum.

\section{Indledning}

Den russiske sophiologi forstår sig som transkonfessionel, teologisk og filosofisk, idet den ønsker at inddrage det bedste fra den tyske idealisme og de græske kirkefædre. At teologi og antropologi er forbundne opfattes ikke som en trussel mod teologien, men som et frugtbart udgangspunkt, som kalder på teologisk refleksion over doktrinen om Guds menneskeliggørelse. Humanitet er således et guddommeligt prædikat. Guds personliggørende visdom: Sophia medierer mellem Gud og mennesket, evighed og tid, enhed og fragmenter.

Denne artikel giver en introduktion til Sergei Bulgakovs teologi og russiske sophiologi. Artiklen gør rede for sophiologiens teologiske og 
dogmatiske relevans ved at lægge vægt på de kristologiske og trinitariske aspekter ved sophiologien. Desuden overvejes en teologihistorisk placering af russisk sophiologi i forhold til Karl Barths dialektiske teologi.

\section{Russisk sophiologi genaktualiseret}

"These are the glory days of Sergii Bulgakov!" Sådan lyder ordene i bogen Encounter Between Eastern Orthodoxy and Radical OrthodoxyTransfiguring the World Through the Word fra 2009. ${ }^{1}$ John Milbank, som er hovedmanden bag den teologiske retning Radical Orthodoxy, udtrykker sin begejstring for russisk sophiologi på følgende måde:

At the dawn of the twenty-first century, it increasingly appears that perhaps the most significant theology of the two preceding centuries has been that of the Russian sophiological tradition. ${ }^{2}$

John Milbanks begejstring gør det oplagt at spørge, hvad er russisk sophiologi? Og hvis den har været så vigtig, hvorfor har man ikke hørt om den? Milbank er ikke alene om interessen for sophiologi og for teologer som Pavel Florenskij og Sergei Bulgakov. Også den norske antologi Moderne teologi, tradisjon og nytenkning hos det 20. àrhundrets teologer fra $2008^{3}$ peger på dens aktualitet. I Danmark er det imidlertid begrænset, hvad man kan fă at vide om russisk sophiologi, hvilket måske burde vække forundring taget sophiologiens nyvundne aktualitet i betragtning. Uden for Danmark findes der dog flere introduktioner til Sergei Bulgakov og hans teologi, som vil blive inddraget nedenfor. I 2002, 2006 og 2008 udkom hans store trilogi for første gang i engelsk oversættelse. Hidtil fandtes den kun på russisk og i fransk oversættelse. Bulgakovs teologiske hovedværker er således de seneste år blevet tilgængelige for et større publikum.

1. Encounter Between Eastern Orthodoxy and Radical Orthodoxy - Transfiguring the World Through the Word, red. Pabst og Schneider (Farrnham: Ashgate 2009), 89.

2. John Milbank "Sophiology and Theurgy. The New Theological Horizon", EBEORO. Pabst \& Schneider (2009), 45.

3. Moderne teologi, tradisjon og nytenkning hos det 20. ärhundrets teologer, red. Johannes Ståle Kristiansen og Svein Rise (Kristiansand: Høyskoleforlaget 2008). Redaktørerne gør i indledningen opmærksom på, at det nye ved deres antologi, i forhold til tidligere antologier, er, at den behandler moderne ortodokse teologer: "Det er første gang en framstilling av det sidste århundres teologi gir en så bred presentasjon av ortodokse enkeltteologer.” Kristiansen og Rise (2008), 27. 


\section{Den sophiologiske tradition}

Den russiske sophiologis tre hovedpersoner er Vladimir Soloviev (1853-1900), Pavel Florenskij (1882-1937) og Sergei Bulgakov (1871-1944). Soloviev var sophiologiens "fader", Florenskij og Bulgakov dens arvtagere.

I en forelæsningsrække over Guds menneskeliggørelse fra årene 1877-1881, udfoldede Soloviev sin sophiologi. Flere prominente personer hørte forelæsningerne, bl.a. Dostojevskij og Tolstoj. Udgangspunktet var Guds menneskeliggørelse, men Soloviev var også inspireret af jødisk kabbala, gnosticisme og mystik, hvilket gjorde sophiologien synkretistisk. Det var det synkretistiske ved sophiologien, som teologerne Florenskij og Bulgakov forsøgte at gennemtænke og forbedre. $^{4}$

Florenskij lagde i sit teologiske hovedværk fra 1914, The Pillar and Ground of the Truth, vægt på ikonografi og den russiske tradition for Sophia-ikoner og den betydning, de har for filosofien og teologien. Ved at knytte Sophia til den hellige tradition, frem for gnostiske og kabbalistiske tekster, videreførte Florenskij arven fra Soloviev på en måde, som styrkede sophiologiens teologiske fundament.

Nærværende artikel skal beskæftige sig med Bulgakovs udformning af russisk sophiologi, for det var med ham, at sophiologien nåede sit teologiske højdepunkt og desuden fandt vej til Vesten.

Det centrale i Bulgakovs sophiologi er, at forholdet mellem Gud og verden forsones, da Gud blev menneske i Kristus, men allerede før verdens skabelse fandtes en guddommelig mediering, som gjorde forbindelsen mulig mellem Gud og verden, ide og fænomen, guddommelighed og menneskelighed. Sophiologi handler om mediering og om dét, som gør det muligt, at identitet og forskel opfattes som forbundne modsætninger. I Bulgakovs sophiologi samles således en filosofisk, politisk og teologisk tænkning under ét. For at betegne Bulgakovs teologi som ortodoks teologi, må man spænde prædikatet ortodoks til det yderste.

\section{Bulgakov - marxist, idealist og præst}

Bulgakov var 47 år gammel, da han blev ordineret som præst i 1918 . Som 13-årig var han begyndt på teologistudiet, men stoppede efter

4. Rowan Williams, "Eastern Orthodox Theology", The Modern Theologians: An introduction to Christian theology since 1918, red. David F. Ford (Oxford: Blackwell Publishing, 2005), 574. 
tre år, da han mistede troen på Gud. Han skiftede studieretning og kastede sig over jura, politik og økonomi. Bulgakov var som mange andre i sin samtid optaget af marxistiske ideer. I år 1900, samme år som hans afhandling udkom om kapitalisme og landbrug, brød han med marxismen og rettede sin opmærksomhed mod idealistisk tænkning og mod spørgsmålet om Gud (Valliere 2001, 231).

I 1912 udkom The Philosophy of Economy, som løftede sløret for en ny dimension i Bulgakovs politiske og idealistiske tænkning, nemlig den sophiologiske. Inspirationskilden til sophiologien var føromtalte Vladimir Soloviev. I 1925 flyttede Bulgakov til Paris. Han havde i et par år levet i eksil på grund af bolsjevikkernes udvisning af russiske intellektuelle i 1922. I Paris blev han udpeget som dekan for det nyåbnede St. Sergei-institut for ortodoks teologi. ${ }^{5}$

\section{Den sophiologiske strid}

Mens Bulgakov var dekan ved St. Sergei-instituttet, rettede patriarkatet i Moskva i 1935 en anklage for kætteri mod ham. Anklagen handlede ikke så meget om sophiologi, men var mere et udtryk for et større magtpolitisk spil mellem patriarkaterne i Moskva og i Konstantinopel, som på den tid kæmpede om den juridiske og politiske magt over den russiske diaspora.

På den mindre scene handlede striden om sophiologi. Striden stod mellem Sergei Bulgakov og Georg Florovskij (1893-1979). Georg Florovskij var ligesom Bulgakov ansat som lærer ved St. Sergei-instituttet i Paris. Han havde i begyndelsen af 1920'erne udtrykt sin reservation over for sophiologien. Det var ikke Sophia, der for ham var problemet, men den russiske Sophia og arven fra Vladimir Soloviev. ${ }^{6}$

Georg Florovskij og Vladimir Losskij (1903-1958) blev nøglepersoner for en patristisk teologi, som opstod som alternativ til den russiske sophiologi. Denne retning fik tilnavnet "den neopatristiske skole”. For dem var det afgørende at forstå kristendommen ud fra en græsk-jødisk (og ikke en russisk) kontekst. Problemet med Bulgakovs sophiologi var for dem at se, at den viklede kristendommen ind i en romantisk og slavofil tradition.

Ifølge religionsprofessor Paul Valliere, hvis forskning har spillet en væsentlig rolle for genaktualiseringen af den sophiologiske tradition, har den russiske sophiologi alt for længe stået i skyggen af den neo-

5. Rowan Williams, Sergii Bulgakov: Towards a Russian political theology (Edinburgh: T\&T Clark 1999), 164-165.

6. Alexis Klimoff, "The Sophiological Controversies”, St. Vladimir's Theological Quarterly 49:1-2 (2005), 67-100 (74). 
patristiske skole. ${ }^{7}$ Hovedårsagen var, at sophiologien var for udfordrende i forhold til de traditionelle rammer om ortodoks teologi. Paul Valliere fastslår, at det karakteristiske for den russiske sophiologi er, at den, i modsætning til den neopatristiske skole, tør forbinde teologi og modernitet. ${ }^{8}$

\section{Det kristologiske udgangspunkt for sophiologien}

Bulgakovs sophiologiske forfatterskab kan deles i to: en tidlig del skrevet i Rusland og en sen del skrevet i Paris. ${ }^{9}$ Den sene del består af trilogien $\mathrm{O}$ Bogochelovechestve, hvis engelske titel er: On Divine $\mathrm{Hu}$ manity. I forhold til den tidligere del er trilogien kendetegnet ved en mere moden teologisk tænkning. ${ }^{10}$ Det vanskelige ord Bogochelovechestvo er et nøgleord i den russiske sophiologi. Det betyder Guds menneskeliggørelse (egentlig gudmenneskehed eller gudsmenneskelighed ${ }^{11}$ ), som ganske vist betegner Guds menneskeliggørelse, men også antyder muligheden af menneskets guddommeliggørelse. I den russiske sophiologi er humanitet en guddommelig bestemmelse. Guddommelighed og menneskelighed opfattes ikke som modsætninger, men forenet gennem inkarnationen.

Grundlæggende er sophiologien i Bulgakovs udlægning et forsøg på at finde et positivt (katafatisk) modspil til kalkedonense og de fire negative (apofatiske) bestemmelser af forholdet mellem Kristi to na-

7. Paul Valliere, Modern Russian Theology. Bukharev, Soloviev, Bulgakov-Orthodox Theology in a New Key (Michigan: Wm. B. Eerdmans Publishing Company 2001), 6.

8. "From the start sophiology was a mediating discipline, a both/and conceptuality envisioning Orthodoxy and modern civilization speaking to each other, reflecting on each other, reflected in each other, walking through history together, confronting the eschatological horizon together." Paul Valliere, "Sophiology as the Dialogue of Orthodoxy with Modern Civilization", Russian Religious Thought, red. Judith Deutsch Kornblatt og Richard F. Gustafson (London: The University of Wisconsin Press, 1996), 187.

9. De tidlige værker i Bulgakovs sophiologiske forfatterskab består af: Philosophy of Economy: the world as household [1912]; La lumière sans déclin [1917]. De senere værker er samlet i den store trilogi: "On divine humanity", som består af The Lamb of God [1933], The Comforter [1936] og The Bride of the Lamb [1945]. Hertil kommer ovennævnte: Sophia, the wisdom of God: an outline of sophiology [1937].

10. Sergei Bulgakov, The Lamb of God, oversat af Boris Jakim (Grand Rapids, Michigan/ William B. Eerdmans Publishing Company 2008), x.

11. Jf. Valliere (2002), 11-15. Valliere oversætter Bogochelovechestvo med "The Humanity of God" og ikke med det mere traditionelle "Godmanhood". 
turer. ${ }^{12}$ Bulgakov anser ikke kalkedonense for en fejlfri og færdig teologi. Den bærer derimod præg af at være et praktisk kompromis indgået mellem teologerne i Antiokia og teologerne i Aleksandria. Kompromiset blev indgået ikke så meget på grund af, at teologerne var nået til enighed, men under tilskyndelse af myndighederne (Bulgakov 2008, 56ff).

Det interessante ved Bulgakovs gennemgang af teologihistorien, både før og efter kalkedonense, er, at han forstår teologi som dét, som bliver til i mødet mellem ortodoksi og kætteri (Bulgakov 2008,1). Teologi er kort sagt en syntese af hæretiske og ortodokse tanker. For dét, som den ene part misforstår, leder til den anden parts præcisering. Bag enhver erklæring om kætteri findes flere udfordrende og derfor befordrende spørgsmål for teologien. Spørgsmål, som ikke må ignoreres, men må tages op og genovervejes.

Bulgakov forstod kristologi som en kontinuerlig refleksion, der aldrig helt kan indfanges og fastholdes i dogmerne. Samtidig fastholdte han, at det er nødvendigt og vigtigt, at fastsætte dogmer, fordi de værner om den sande tro og beskytter mod vranglære. Denne dobbelthed skaber en dialektik mellem, på den ene side den normative udformning af dogmer, på den anden side den vedvarende teologiske refleksion herom.

Det positive supplement til kalkedonense handler for Bulgakov om mulighedsbetingelsen for, at det guddommelige og det menneskelige overhovedet kan forenes uden at sammensætningen blive på bekostning af det menneskelige eller det guddommelige. Sophia er denne mulighedsbetingelse. Hun findes fra evigheden af som mediering af Guds menneskeliggørelse i inkarnationen og menneskets guddommeliggørelse i det evige. ${ }^{13}$

Sophiologiens opgave er knyttet til kristologien. At Kristus blev menneske betyder nemlig, at noget i Gud er i stand til at blive til menneske, og tilsvarende at noget i det menneskelige kan bære at blive guddommeliggjort.

12. "Jesus Kristus fuldstændigt menneske og fuldstændig Gud" er som bekendt den centrale formulering i Kalkedonense fra kirkemødet i Kalkedon i 451. Kalkedonense beskriver forholdet mellem Kristi to naturer ud fra fire negative udsagn: de to naturer er: (a) uden sammenblanding, (b) uden forvandling, (c) uopløselige og (d) uadskillelige. Disse udsagn udgjorde et værn imod en række kætterier, som misforstod eller fejlaccentuerede forholdet mellem Kristi to naturer.

13. "The Divine-Humanity and the God-Man, that is the humanity of Divinity and the divinity of humanity, are given pre-eternally in God.” Bulgakov (2008), 114. 


\title{
Teologisk Weltanschaunng
}

I 1934 udgav Bulgakov på engelsk en redegørelse for sin sophiologi. Her skriver han:

\begin{abstract}
Sophiology represents a theological or, if you prefer, a dogmatic, interpretation of the world (Weltanschauung) within Christianity. It is characteristic only of one trend of thought within Christianity, and that one which is by no means dominant in the Orthodox Church, just as, for instance, Thomism or "Modernism" exists within Catholicism, or liberal "Jesuanism" or Barthianism within Protestantism. The sophiological point of view brings a special interpretation to bear upon all Christian teaching and dogma, beginning with the doctrine of the Holy Trinity and the Incarnation and ending with questions of practical everyday Christianity in our own time. ${ }^{14}$
\end{abstract}

Sophiologien vil således ikke opfattes som en trend inden for ortodoks teologi. Den vedrører al teologi, fordi den vedrører forholdet mellem Gud og menneske, og tillige betingelsen for forholdet. I vestlig teologi er der tradition for at tale om betingelsen for dette forhold ud fra forskellige analogier (analogia entis, analogia fidei, analogia imaginis ${ }^{15}$ ). Både analogien, betingelsen og forholdet mellem Gud og mennesket begrebsliggøres hos Bulgakov i sophiologien. Virkeligheden har en evig og himmelsk oprindelse, som medieres af og gennem Sophia.

Bulgakovs russiske sophiologi kom til at fremstå som en uortodoks russisk-ortodoksi, fordi dens begyndelse skete uden for (men hen imod) kirken og endelig uden for Rusland. På dette punkt er kontrasten stor til den dialektiske teologi, som opstod som en kirke- og præsteteologi. Der er dog et muligt anknytningspunkt mellem Barth og Bulgakov, som skal præsenteres i det følgende.

\section{Barth om Guds menneskelighed}

Karl Barths (1886-1968) teologi fremstår som den diametrale modsætning til sophiologien, fordi hans teologi er kendt for at være en teologi von oben, hvor sophiologien er en teologi von unten nach oben (Valliere 2001, 14). Hjertet i begge tilgange er spørgsmålet om forholdet mellem Gud og menneske, og hvordan dette forhold udtrykkes. Barths erklæring om teologiens krisis sætter mennesket i en posi-

14. Sergei Bulgakov, Sophia - The Wisdom of God - An Outline of Sophiology. Library of Russian Philosophy. (Hudson, N.Y.: Lindisfarne Books 1993), 13.

15. Svarende henholdsvis til de teologiske positioner hos Erik Pryzwaras, Karl Barth og Paul Tillich. 
tion, hvor det over for Gud intet formår. Menneskets uformåen er dog samtidig en åbning for, at Gud formår det, som mennesket ikke formår. Forholdet mellem Gud og menneske er med andre ord muliggjort fra oven. Dette udtrykte Barth mest radikalt i Romerbrevskommentaren fra 1922, men det findes også i hans Kirkelige Dogmatik, i kritikken af naturlig teologi og analogia entis.

Senere i livet fastholdt Barth positionen mindre radikalt, og i 1956 skrev han, i en lille bog med titlen Die Menschlichkeit Gottes, at opgaven for fremtidens teologer bliver at redegøre for Guds menneskelighed - til forskel fra (og ikke i modsætning til) hans teologi igennem de sidste 40 år, som har fokuseret på Guds guddommelighed. Dette fremgår af følgende citat:

Ich täusche mich wohl nicht, wenn ich annehme, daß das uns heute gestellte Thema jedenfalls auch ein Hinweis sein sollte auf eine Wendung im Denken evangelischer Theologie, in der wir heute - nicht im Gegensatz, aber doch im Unterschied zu einer früheren Wendung begriffen sind oder begriffen sein sollten. Was sich uns vor nun rund vierzig Jahren stürmisch aufzudrängen begann, war ja weniger die Menschlichkeit als die Göttlichkeit Gottes: (...). Ich wäre wohl in eine gewisse Verlegenheit geraten, wenn man mich etwa im Jahre 1920 - dem Jahr, in dem ich in diesem Saal meinem großen Lehrer Adolf von Harnack gegenüberstand - aufgefordert hätte, über die Menschlichkeit Gottes zu reden. ${ }^{16}$

Barth beretter, at han ville være bragt i forlegenhed, hvis han i 1920erne var blevet bedt om at redegøre for Guds menneskelighed. I forlængelse af citatet kan sophiologien udpeges som en videreførelse af teologien efter Barth, for det er netop "die Menschlichkeit Gottes", som her er det centrale (Valliere 2001, 14).

Det er slet ikke utænkeligt, at Barth og Bulgakov kendte til hinanden og til hinandens teologi. I 1931 var Barth til et seminar, som Georg Florovskij holdt. Florovskij var på dette tidspunkt ansat ved St. Sergei instituttet i Paris, hvor Bulgakov var dekan. Seminaret finder sted fire år før den sophiologiske strid når sit højdepunkt med kætterianklagen og det efterfølgende brud mellem Bulgakov og Florovskij. ${ }^{17}$ Florovskijs neopatristiske tilgang til teologien har givetvis været lettere begribelig for Barth end Bulgakovs sophiologi, men også Florovskijs teologi gjorde et sådan indtryk på Barth, at han samme år

16. Karl Barth, Die Menschlichkeit Gottes, Theologische Studien Heft 58 (ZollikonZürich: Evangelischer Verlag AG 1956), 3-4.

17. Florovskij underskrev, som den ene af to, kætterianklagen mod Bulgakov. 
i et brev til Eduard Thurneysen erklærede sig mere på linje med katolikker end med ortodokse. ${ }^{18}$

Til trods for iøjefaldende forskelle mellem russisk ortodoksi og den tidlige dialektiske teologi, er sophiologiens overordnede opgave rettet mod en fortolkning af teologien med udgangspunkt i Guds menneskelighed (jf. Bulgakov-citatet ovenfor). Barths tekst fra 1956 kan derfor siges at kredse om det, som er udgangspunktet for Bulgakovs sophiologiske teologi. Selvom Barth ikke udtaler sig om russisk sophiologi, er det tydeligt, at han anerkender og imødegår dens opgave om og udgangspunkt i Guds menneskelighed. Herved understreges Bulgakovs pointe om, at sophiologien er et anliggende for al teologi og ikke kun en bestemt gren af den.

\title{
Sophiologisk krisis
}

Hos Bulgakov finder man henvisninger til 'barthianisme' og en bevidst brug af barthiansk terminologi. Omfanget af Bulgakovs kendskab til Barth er denne forfatter ubekendt. I Sophia The Wisdom of God, An Outline of Sophiology, anvender Bulgakov i sin indledning ord som "dialektik" og krisis (i anførselstegn og kursiveret), hvilket er åbenlyse henvisninger til Barths teologi. Afsnittet er værd at citere i fuld længde:

\begin{abstract}
We must discover how we can overcome the secularizing forces of the Reformation and the Renaissance, not in a negative way or "dialectically," which is in any case merely theoretical and powerless, but in a positive way - through love for the world. But again we repeat that this can be accomplished only through a change in our conception of the world, and through a sophianic perception of the world in the Wisdom of God. This alone can give us strength for new inspiration, for new creativity, for the overcoming of the mechanization of life and of human beings. The future of living Christianity rests with the sophianic interpretation of the world and of its destiny. (...) For this reason, in the true sense of the word, sophiology is a theology of crisis, not of disintegration, but of salvation (Bulgakov 1993, 21).
\end{abstract}

For Bulgakov er kristendommen forpligtet på en kritisk, men også frelsesorienteret fortolkning af verden, det vil sige en fortolkning af verden gennem Ordet. Verden er splittet, men splittelsen er samtidig ikke det afgørende, det er derimod frelsen. Den sande teologiske krisis består $\mathrm{i}$, at verden i virkeligheden er Guds. 
På samme måde som Barth har sans for sophiologiens opgave, har Bulgakov sans for Barths krisis. Forskellen på den barthske krisis og den bulgakovske er, at baggrunden for førstnævnte er en apofatisk teologi, for sidstnævnte en katafatisk teologi. Bulgakovs katafatiske teologi er, ifølge ham selv, på paradoksal vis en konsekvent apofatisk teologi. Den negative antagelse: at den absolutte Gud ikke kan begribes med menneskelig fornuft, er i sig selv en antagelse, som overskrider negativiteten, ifølge hvilken intet kan antages. Konsekvensen af en konsekvent negativ teologi er en positiv teologi! Bulgakov forklarer det således:

Now it is true that the absolute God can never be comprehended by human reason. God transcends the world and humankind to such an extent that even the purely negative theology which denies all possibility of knowing anything about God, has nevertheless already gone too far in affirming so much as that. Even negation must make one positive assumption. God in his mercy [...] reveals himself to us both in his tripersonal being and in the simplicity of his deity, and only by virtue of such revelation dare we make any positive statement about God; we not only may, we must (Bulgakov 1993, 60).

Den katafatiske teologi overgår den apofatiske teologi takket være Guds selvåbenbaring $\mathrm{i}$ inkarnationen, som samtidig er betingelsen for vores tale om Gud. Den sophiologiske krisis er således omfattet af en katafatisk teologi, hvor verden ikke afskrives, men indgår i en større frelsesplan.

\section{Det trinitariske udgangspunkt for sophiologien}

Hos kirkefædrene og hos apostlen Paulus regnes Sophia for et attribut til Kristus Logos. For Bulgakov er det vigtigt, at Sophia forstås ud fra Treenigheden (Bulgakov 2008, 203, 110 note 16). På dette punkt bryder Bulgakov med traditionen, idet han fortolker Sophia trinitarisk.

Sophia er ingen fjerde person i Treenigheden, hun tilføjer ikke noget nyt, men er en måde at mediere den kontrære samtidighed af Én og Tre i Treenigheden på. I Sophia åbenbares Sønnen og Helligånden samtidigt, og denne åbenbaring åbenbarer Faderen (Bulgakov 2008, 110). Sophia er det hypostatiserende, det vil sige personliggørende ved Guds herlighed og visdom.

Bulgakov skriver, at det er vigtigt for teologien at grunde over det personlige aspekt ved Guds natur, for ingen benægter eksistensen af Guds natur. At Guds natur skulle have et personligt aspekt er heller 
ikke ensbetydende med, at der føjes en ny person til Treenigheden. Uenigheden opstår først, indrømmer Bulgakov, når det personliggørende aspekt ved Guds natur kaldes Sophia (Bulgakov 2008, 97, note 3). Bulgakov påpeger således, at det afgørende ikke er sophiologien, men det personlige ved og i Guds natur. Sophiologien er dog netop et forsøg på at beskrive og begrebsliggøre dette.

Sophia er ikke Gud. Gud er Sophia, men Sophia er ikke Gud. Sætningen kan ikke vendes rundt, for der er et ulige og irreversibelt forhold mellem subjekt og prædikat.

God is Ousia. The reverse, however, is not true: Ousia is not (the personal) God; Divinity is not the Divine Personality. Likewise God is Sophia; Sophia is divine. She is God in his self-revelation, Deus revelatus, although the reverse, again, is not true: Sophia is not ho Theos but only theos or Theos [uden artikelen "ho"] (Bulgakov 2008, 102).

Bulgakov fastholder, at Sophia ikke er en person, en hypostasis, hun er heller ikke en ikke-hypostasis. Hun er hypostatiserende. Hun er den personliggørende guddommelighed, herlighed og visdom. Der findes to grundlæggende aspekter ved Sophia, det guddommelige og det jordiske. De to aspekter skal ikke forstås dualistisk, men i et dialektisk forhold mellem den skabte og den skabende natur - natura naturata og natura naturans. ${ }^{19}$ I denne betydning er det klart, at Sophia ikke er to, men én og samme. Hun er den, som hypostatiserer, samtidig er hun også den, som gør det muligt for den skabte væren at være sig selv og noget andet på samme tid, uden at den skabte væren af den grund bliver skizofren eller dualistisk. ${ }^{20}$

\section{Skabelse som metafysisk begivenhed}

Den skabte væren er en metafysisk kendsgerning (Bulgakov 2008, 123). Bulgakov forstår hermed, at dét, som formgiver menneskets viden og væren, er afledt af den evige Guds skabelse af den tidslige verden. Det er således ud af skaberværket som metafysisk begivenhed, at

19. Bulgakov (2008), 89-101. Det er ikke kun den dialektiske identitet mellem natura naturata og natura naturans, der interesserer Bulgakov, det er også mediationen, som sammenholder distinktionen: "Between natura naturans and natura naturata there exisists a living identity" Bulgakov (2008), 90.

20. John Milbank bemærker, at hvis der ikke fandtes en mediering i forholdet mellem "the engendering" (natura naturans) og "the engendered" (natura naturata) så ville "the engendered" være "sheerly 'other' to the engendering". John Milbank (2009), 45. Den sophiologiske mediering sikrer med andre ord, at den vedvarende skabelse af skabningen ikke sker fremmedgørende (alienerende), men medierende. 
mennesket får sin viden og sin væren. ${ }^{21}$ Sand ontologi har sin rod i evigheden og ernæres metafysisk. Det betyder ikke, at det er bag tingene, at de sande og uforanderlige ideer findes og heller ikke kun i tingene. I den skabte væren findes en metafysisk erindring af skabelsen. Den kan ikke begribes med forstanden, men må gribes i troen, som åbenbares.

Konsekvensen af Bulgakovs ontologi er, at verden findes i en samtidighed af enhed og forskel, i en samtidighed af sammentræffende modsætninger. Menneskets viden om verden og sig selv strander ultimativt foran den "fysiske antinomis flammesværd" (Bulgakov 2008, 123). Den metafysiske begivenhed, der grundlægger verden, er ikke tilgængelig for fornuften, men er det i troen og i skønhedserfaringen af skaberværkets "sophianicitet".

Bulgakov bruger ordene sophiansk og sophianicitet som udtryk for den personlige formidling imellem Gud og verden. Det er i kraft at verdens sophianicitet, at mennesket kan træde ind over grænsen til det uendelige. Overskridelsen er ikke en kompromittering af Gud, for Gud selv tilvejebringer og er overskridelsen.22 Gud er fri til at være sig selv også i dét, som ikke er Gud.

Da Gud skabte verden førte Han sit indre guddommelige liv ud i det ydre. Bulgakov taler i denne forbindelse om Faderens evige kenosis $^{23}$ (Bulgakov 2008, 98-99, 128-129). Ved at sætte Sønnens kenosis i relation til Faderens evige kenosis, fremhæver Bulgakov evighedens og Treenighedens tilstedeværelse i Kristus-begivenheden. Samtidig fremhæver han de antropologiske og soteriologiske aspekter ved Kristus-begivenheden, fordi den aktualiserer, at mennesket allerede er skabt til et liv i guddommelighed og nu tillige frelst. Sophiologien er med andre ord et forsøg på at sætte ord og begreb på det "kenotiske" forhold mellem kristologi og Treenighed.

21. Min gengivelse af Bulgakov følger her den franske oversættelse, hvor den metafysiske kendsgerning fastsatter menneskets viden og væren, og ikke (som i den engelske oversættelse) konfronterer dem ("prendre asseoir" vs. "confront") På engelsk lyder sætningen: "The givenness or creatureliness is a metaphysical fact that our consciousness and our beeing necessarily confront" (Bulgakov 2008, 123). På fransk: "Cet état donné ou crée est le fait métaphysique où prennent assise notre conscience et notre être." (Bulgakov 1943, 43).

22. Bulgakov (2008), 121: "The world cannot surmount the abyss that lies between the Creator and creation, but God Himself surmounts it."

23. Grundbetydningen af kenosis, af verbet, er udtømning. Ordet optræder i Filliperbrevshymnen (Fil. 2,6), som beretter om Sønnen, som "gav afkald på det "at være lige med Gud." 


\section{Hans Urs von Balthasar}

Den katolske teolog Hans Urs von Balthasar (1905-1988) er på dette punkt inspireret af Bulgakov. I sit fembinds værk: Theodramatik fra 1973-1983, udfolder Balthasar en trinitarisk kristologi, hvor han ligger vægt på, at Jesus' sendelse er Sønnens udgåen fra Faderen (hans missio er hans processio). ${ }^{24}$ Traditionelt set aflæses den immanente Treenighed ud fra den økonomiske, således at vores viden om Treenighedens tre personer og ene natur findes på baggrund af den økonomiske, det vil sige frelseshistorisk. Det er denne tradition, som Balthasar - inspireret af Bulgakov - gennembryder med en trinitarisk inversion (Balthasar 1990, 207, 220). Takket være Faderens evige kenosis, som er model for Sønnens kenosis (Balthasar henviser her til Bulgakov ${ }^{25}$ ), kan vi vide noget om den Treenige Gud uden for frelseshistorien, nemlig at den Treenige Gud essentielt set er kærlighed. Med sin trinitariske inversion placerer Balthasar sig på en måde mellem Karl Barth og Sergei Bulgakov.

\section{Sophiologiens teologiske komposition}

In Himself God is thus the Absolute, but for the world He is the Absolute-Relative, existing in Himself but also outside of Himself (Bulgakov 2008, 122).

Når Bulgakov omtaler Gud som den Absolutte og som den AbsolutRelative, synes det at svare til distinktionen immanent og økonomisk Treenighed, Gud for sig og Gud for os. Spørgsmålet er imidlertid, om denne sondring er passende i forhold Bulgakovs teologi. Bulgakov forklarer, at Gud er inden for og uden for sig selv samtidigt, og henviser til den græske teolog Gregor Palamas (1296-1359).

Palamas ville med sin distinktion ousia og energeia fastholde, at Guds ousia er utilgængelig for skabningen, men tilgængelig gennem Guds energeia. Spørgsmålet er naturligvis, hvordan det er muligt og meningsfuldt at fastholde Guds tilgængelighed og utilgængelighed samtidigt. Hvordan kan det utilgængelige (ousia) gøres tilgængeligt (energeia) uden at kompromittere Gud (Deus absconditus)? Ifølge Bulgakov er svaret, at Gud på en og samme tid er Absolut og AbsolutRelativ (Bulgakov 2008, 122). Sammenligner man med begreberne økonomisk og immanent Treenighed, så har Bulgakovs Treenigheds-

24. Hans Urs von Balthasar, Theodramatik, Band 2/2: Die Personen in Christus (Einsiedeln: Johannes Verlag 1990), 208.

25. Hans Urs von Balthasar, Theodramatik, Band 3: Die Handlung (Einsiedeln: Johannes Verlag 1980), $291 \mathrm{ff}$. 
lære mere tilfælles med Hans Urs von Balthasars end med Karl Rahners. Balthasar fastholder nemlig, at ligheden overgås af en større ulighed. ${ }^{26}$

Den treenige Gud er ikke ud fra et bestemt perspektiv immanent og fra et andet økonomisk. Den Treenige Gud er vedvarende og samtidigt begge dele. Denne antinomiske position, som synes umulig at fastholde, er ikke desto mindre den, som Bulgakov i sin sophiologi er optaget af, og som han kalder for Sophia. Her en iagttagelse af John Milbank, som fanger dette:

(...) one can take sophiology as the attempt to think through the place of mediation in instances like the theological ones mentioned where, it would seem, there cannot possibly be any mediation and yet, without it, everything threatens to fall apart. To anticipate, one could say that Sophia names a metaxu which does not lie between two poles but rather remains simultaneously at both poles at once (Milbank 2009, 50).

Det græske adverbium $\mu \in \tau \alpha \xi u$ betyder derimellem. Sophia muliggør den ellers umulige position mellem Gud inden for sig selv og uden for sig selv samtidigt. Sophia er evig og tidslig, og dog er hun den samme. Der ligger en særlig logik til grund for den kontrære tænkning, som er optaget af det derimellem varende.

Den antinomiske enhed er tænkt ud fra en kontrær logik, som kan sættes på formlen: "A = $A$ ". Formlen udsiger, at A er A og ikke-A på samme tid. Det er på denne måde, at antinomien: Guds ousia og energeia, Gud i sig selv og uden for sig selv, må forstås som en kontrær enhed, hvor den ene part ikke ekskluderer den anden, men hvor begge fastholdes i en enhed. Det er her nærliggende at henvise til Pavel Florenskij, som også nævntes indledningsvist.

\section{Kontrar logik}

Teorien om kontradiktionen som en egenskab ved sandheden findes mest udførligt udfoldet hos den russiske matematiker, filosof, teolog, præst, digter, fysiker, historiker, ingeniør og sophiolog Pavel Florenskij (1882-1937). I sit hovedværk, hvis engelske titel er The Pillar and Ground of The Truth, retter han en skarp kritik mod fornuftstænkningen. Florenskij kritiserer fornuften for at mangle intuition og for blindt at adlyde kontradiktionsprincippet, ifølge hvilket $\mathrm{A}$ og ikke-A gensidigt udelukker hinanden. Dette behandles flere ste-

26. Jf. Rowan Williams, "Balthasar and the Trinity", The Cambridge Companion to Hans Urs von Balthasar, red. Edward T. Oakes SJ og David Moss (Cambridge: Cambridge University Press 2004), 38 og 43. 
der, men grundigst i kapitlerne Doubt og Contradiction. Problemet ifølge Florenskij er, at fornuften kun anser bekraftelsen af det varende for sandt. Udsagn om det ikke-varende regnes for doxa, skin og ikke for gyldige udsagn. Det skal indskydes, at doxa kan betyde mening, antagelse, (grundløs) formodning, men paradoksalt nok, kan det også betegne den sande lære. Denne ambiguitet passer fint sammen med Florenskijs logik.

Ifølge Florenskij opererer fornuften ud fra en tom og tautologisk lov: $A=A$. Denne lov formår ikke at forklare $A$, fordi $A=A$ forklarer A som et andet A, som et A uden for (og på den anden side af) A. ${ }^{27}$ Det "fornuftige", som opererer ud fra A = A, er ubegrundet, fordi noget begrundes som noget andet, hvilket svarer til $\mathrm{A}=\mathrm{B}$, som er en $k a$ mufleret tautologi, for hvis $\mathrm{A}=\mathrm{B}$, så er $\mathrm{B}=\mathrm{A}$, og så siger sætningen ikke andet end det samme, dvs. den kan omskrives til: A = A. Så længe A udlægges som $\mathrm{A}$ = A forbliver A ontologisk set tomt, og fornuften forbliver uudgrundelig og kontraintuitiv.

Som alternativ til fornuftens identitets lov fremsætter Florenskij en forståelse af sandheden som antinomisk. Det sande udsagn er ifølge Florenskij i stand til at modsige sig selv. Han forklarer det i følgende passage, som jeg citerer i fuld længde:

A rational formula can be true if and only if it foresees, so to speak, all objections to itself and answers them. But to foresee all objections, it is necessary to take not them concretely but their limit. It follows that truth is a judgment that also contains the limit of all its refutations, or (in other words) that truth is a self-contradictory judgment. Therefore, truth is truth precisely because it is not afraid of any objections. And it is not afraid of them because it itself says more against itself than any negation can say, but truth combines this its self-negation with affirmation. For rationality, truth is contradiction, and this contradiction becomes explicit as soon as truth acquires a verbal formulation. (...) The thesis and the antithesis together form the expression of truth. In other words, truth is an antinomy, and it cannot fail to be such. (Florenskij 1997, 109).

27. Pavel Florenskij, The Pillar and Ground of the Truth. An Essay in Orthodox Theodicy in Twelwe Letters, oversat af Boris Jakim (Princeton/Oxford: Princeton University Press [1914] 1997), 23: "The law A = A becomes a completely empty schema of self-affirmation, a schema that does not synthesize any real elements, anything that is worth connecting with the "=" sign. I = I turns out to be nothing more than a cry of naked egotism: "I!" For where there can be no difference, there can be no connection." 
Teorien om kontradiktionen som en egenskab ved sandheden, og sandheden som en antinomi, demonstrerer Florenskij gennem matematiske og logiske formler, som lidt forsimplet kan gengives:

$A=-$ A. Florenskij anvender mere udførlige formler som fx:

$$
\mathrm{P}=(\mathrm{p} \cap-\mathrm{p}) \cap \mathrm{V}^{28}
$$

Men hvad kan vi bruge den kontrære logik til? Er det antinomiske sandhedsbegreb ikke forklædt skepticisme eller nihilisme? Pointen med den antinomiske tænkning er at kritisere fornuftstænkningen. Men pointen er også, at ved at fastholde kritikken ledes man hen imod en anden form for erkendelse. En erkendelse, hvor fornuften bliver intuitiv og erfaringsbaseret. Den sande erkendelse er uudgrundelig for fornuften, men for intuitionen og sansningen er den indlysende.

Den sandhedssøgende og den tvivlende bevæges i sandhedens antinomi mod fortabelse eller kærlighed, tertium non datur. Den sande erkendelse er en kærlighed til livet og til viden, filosofi. Filosofi leder således frem mod et skift $\mathrm{i}$ aspekt fra væren til kærlighed, fra ontologi til metafysik.

\section{Metafysisk ontologi}

Det antinomiske sandhedsbegreb ligger til grund for teologiens dialektiske forhold mellem enhed og forskel. Sand ontologi er ifølge Florenskij og Bulgakov en metafysisk ontologi. Det dennesidige og det hinsides eksisterer side om side i en paradoksal, modsætningsfuld samtidighed, coincidentia oppositorum. ${ }^{29}$ Men hvordan er det muligt? Hvordan kan den modsætningsfulde samtidighed tænkes? Den kan tænkes, begribes og udtrykkes takket være Sophia, den trinitariske $\mu \in \tau \alpha \xi \mathrm{u}$. Sophia er det medierende princip, den personlige formidler mellem Skaber og skabning.

I Guds natur findes et overskud af herlighed, som søger et objekt at være herligt for. Overskuddet er Guds billede af sig selv, "the selficon of Divinity" (Bulgakov 2008, 103). Gud har ikke brug for et objekt andet end sig selv, men Hans herlighed, som åbenbarer sig i det andet, har en skabende og ontologisk afsmittende kraft. En skabelse ud af intet, men samtidig ud af et overskud. "He reflected Himself in nonbeing" (Bulgakov 2008, 126). 
Verden må hos Bulgakov forstås i denne skabelses dialektik mellem intet (ex nibilo) og overskud. Sand ontologi er metafysik. Men "er" i denne sætning er ikke bare "er", men et kærlighedens "er" (Bulgakov 2008, 104). Det er det personlige aspekt ved væren, som sammensætter og forener identitet og forskel.

Forskellen på ontologi og metafysisk ontologi, er, at sidstnævnte antager et medierende princip for, at ideer og fænomener kan forenes. Bulgakov sammenligner Aristoteles' ide om den ubevagede bevager med en horisontlinje, hvor himlen og jorden mødes, men mødet forbliver upersonligt. ${ }^{30}$ I den metafysiske ontologi er dette møde medieret. Det er ikke begribeligt for forstanden, men for erfaringen og for kærligheden til væren. Sandheden om den metafysiske ontologi er ikke en besiddelse, men et metafysisk fact.

\section{Afslutning}

Bulgakovs russiske sophiologi ville mere end at forny teologien og forsvare en bestemt teologisk retning. Den ville udbrede teologien til også at kunne tage højde for den moderne humanismes erfaringer og erkendelser. Derfor nåede den katolske nouvelle théologie med teologer som Henri de Lubac (1896-1991) og Hans Urs von Balthasar (1905-1988), ifølge John Milbank først afslutningsvist frem til det punkt, som var udgangspunktet for den russiske sophiologi:

(...) it seems to me that the scope, ambition and modernity of Russian theology is greater than that of their Latin contemporaries. They tended to start at the point where de Lubac and Balthasar, to name but the most considerable names in the West, only finally arrived (Millbank 2009, 47). ${ }^{31}$

I den russiske sophiologi fastholdes spændingen mellem metafysik og ontologi. I den skabte væren er det gode, sande og skønne forenet, ikke som en teoretiske erkendelse, men tilgængeligt som sand indsigt,

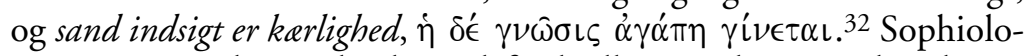
gien er en verdensanskuelse, ud fra hvilken verdens ontologiske og metafysiske komposition er mulig takket være det personlige aspekt ved Guds natur, Sophia. Den metafysiske ontologis realitet er ikke

30. Sergei Bulgakov, The Bride of the Lamb, oversat af Boris Jakim (Michigan: William B. Eerdmans Publishing Company, 2002), 21.

31. Det fremgår af sammenhængen, at Milbank med "Russian Theology" mener den russiske sophiologi.

32. Gregorius af Nyssa. Citeret fra Florenskij (1997), 65 note 115. 
nogen fordobling af verden, men et vidnesbyrd om, at der forud for fænomenologiens sammensætning af ideer og fænomener, findes en guddommelig mediering i skaberværket. Styrken ved denne tilgang til teologiske spørgsmål er, at den respekterer, at der findes forskellige spørgehorisonter, men også at der findes en Sandhed, som er virkeligere end de andre. Ikke ved et tilfælde eller fordi den er vores, men fordi Sandheden korresponderer med sandheden.

Der findes sandhed og Sandhed, fornuftig indsigt og sand indsigt, men noget er skønnere og mere dragende end noget andet. Det er her på sin plads at citere den russiske forfatter F.M. Dostojevskijs (18211881) credo:

Hvis nogen bragte mig beviset for, at sandheden om vort liv ikke er i Kristus, og hvis sandheden i virkeligheden ikke var hos Kristus, så ville jeg hellere være med Kristus end med sandheden. ${ }^{33}$

Pointen er ikke, at sandhed og Kristus modarbejder hinanden, men at Kristus som sandhed er en elskværdig Sandhed, som ikke kræver bevis. Det større er samtidig det sandere og skønnere. At der findes sådanne overskud er ikke tilfældigt, men et kendetegn for skaberværkets iboende Sophia.

Med udgangspunkt i doktrinen om Guds menneskelighed er sophiologien i stand til at redegøre for betydningen af, at mennesket er skabt i Guds billede og at dets verden ikke først og fremmest er en verden i forfald, men Guds selvspejling $i$ intet.

Jeg har med denne artikel forsøgt at give et indblik i, hvad russisk sophiologi er, og hvilken rolle den har i Bulgakovs teologi. Ligeledes har jeg forsøgt at placere sophiologien i forhold til Karl Barths teologi. Pointen med begge dele har været at påvise, at med udgangspunkt i doktrinen om Guds menneskelighed er sophiologien en teologi von unten. Den er af betydning for teologien som sådan, og ikke kun for en bestemt gren af den.

33. Teksten optræder to steder, lettere modificeret. Første gang hos forfatteren selv, i et brev han sendte fra Sibirien i 1854. Anden gang i romanen De besatte, F.M. Dostojevskij, Samlede varker, oversat af Ejnar Thomassen (København: Stig Vendelkærs forlags udgave 2006) Se De besatte, bind 1, 252 og Dostojevskijs breve, bind 1,86 . 